\title{
Psikolojik Dayanıklılığın Covid-19 Korkusu Üzerine Etkisi: Bir Alan Araştırması ${ }^{1}$
}

\author{
Salih YEŞIL
}

Prof.Dr., Kahramanmaraş Sütçü İmam Üniversitesi

İktisadi ve İdari Bilimler Fakültesi, İşletme Bölümü syes66@hotmail.com

Orcid ID: https://orcid.org/0000-0003-3237-2258

\section{Yüksel MAVí}

Doktora Öğrencisi, Kahramanmaraş Sütçü İmam Üniversitesi

İktisadi ve İdari Bilimler Fakültesi, İşletme Bölümü yuksel4689@hotmail.com

Orcid ID: https://orcid.org/0000-0002-9724-7135

\section{Öz}

Bir örgütün devamlılı̆̆ 1 ve başarısı için çalışanlar oldukça önemlidir. Örgüt, çalışanları olduğu sürece hayatını devam ettirecek ve çalışanlarının başarısı sayesinde istediği konuma gelebilecektir. Çalışan ise gerek iş gerekse özel hayatında birtakım zorluklarla karşılaşmaktadır. Bu noktada yüksek psikolojik dayanıklılığa sahip çalışanlar zorluklarla mücadelede daha etkin olduklarından örgütler için daha fazla değerlidirler. $\mathrm{Bu}$ araştırmanın amacı, psikolojik dayanıklılık ve boyutlarının (kendini adama, meydan okuma ve kontrol) Covid19 korkusu ve boyutları (psikolojik faktörler, psiko-somatik faktörler, ekonomik faktörler ve sosyal faktörler) üzerine etkisini incelemektir. Araştırmanın örneklemini Kahramanmaraş'taki bir AVM'nin 169 çalıșanı meydana getirmektedir. Araştırma verilerini toplamak için anket tekniğinden faydalanılmıştır. Araştırma verileri SPSS 25.0 programında frekans analizi, güvenirlik analizi, korelasyon analizi ve regresyon analiziyle test edilmiştir. Analiz sonucunda psikolojik dayanıklılık ve boyutlarının (kendini adama, meydan okuma ve kontrol) Covid-19 korkusu ve boyutlarını (psikolojik faktörler, psiko-somatik faktörler, ekonomik faktörler ve sosyal faktörler) etkilemediği belirlenmiştir.

Anahtar Kelimeler: Psikolojik Dayanıklılık, Covid-19 Korkusu.

\footnotetext{
${ }^{1}$ Makale Geliş/Kabul Tarihi: 12.04.2021/07.07.2021

Künye Bilgisi: Yeşil, S. ve Mavi, Y. (2021). Psikolojik dayanıklılığın Covid-19 korkusu üzerine etkisi: Bir alan araştırması. Kahramanmaraş Sütçü Imam Üniversitesi Sosyal Bilimler Dergisi, 18 (3), 2281-2307. DOI: 10.33437/ksusbd.913890.
} 


\title{
The Effect of Psychological Resilience on The Fear of Covid-19: A Field Research
}

\begin{abstract}
Employees are very important for the continuity and success of an organization. The organization will survive as long as it has employees and will be able to reach the desired position due to the success of its employees. Employees face some difficulties both in their professional and private life. At this point, employees with high psychological resilience are more valuable for organizations as they are more effective in dealing with difficulties. The aim of this research is to examine the impact of psychological resilience and its dimensions (commitment, challenge, and control) on fear of Covid-19 and its dimensions (psychological factors, psycho-somatic factors, economic factors and social factors). The sample of the research consists of 169 employees of a shopping mall in Kahramanmaraş. Questionnaire technique was used to collect research data. The research data were tested with frequency analysis, reliability analysis, correlation analysis and regression analysis in SPSS 25.0 program. As a result of the analysis, it was determined that psychological resilience and its dimensions (commitment, challenge and control) did not affect the fear of Covid19 and its dimensions (psychological factors, psycho-somatic factors, economic factors and social factors).
\end{abstract}

Keywords: Psychological Resilience, Covid-19 Phobia.

\section{GíRIŞ}

İnsanoğlu yaşamı boyunca günlük sıkıntılardan büyük yaşam olaylarına kadar bazı zorluklarla karşı karşıya kalabilir. Genellikle mesleki ve bireysel hayatta böyle zorluklardan kaçınılamamaktadır (Buz ve Genç, 2019: 624). İnsanın

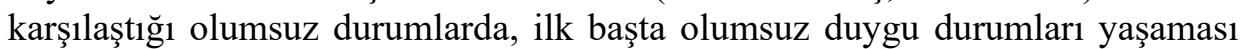
söz konusu olsa da zamanla bu tür durumlara uyum sağlayabilmektedir (Garmezy, 1991). Psikolojik dayanıklılığın tarihte ortaya çıkışı tıp alanındadır. Davranış bilimlerindeki psikolojik dayanıklılık çalışmalarının ise tarihsel olarak 1970'li y1llarda ortaya çıkmaya başladığ görülmüştür (Masten ve Obradovic, 2006: 13-14). Bu noktada mesleki ve kişisel yaşamımızda psikolojik dayanıklılığ inşa edebilmek, zor durumlara başarılı biçimde karşı koymak açısından önemlidir (Mc Ewen, 2011: 3). Psikolojik dayanıklılığı inşa etmek içinde bunun önündeki güçlüklerin saptanması ve bu konudaki kanıtların artış göstermesinin büyük önem taşıdığı düşünülmektedir (Buz ve Genç, 2019: 638). Nitekim psikolojinin kişinin zayıf yönlerini incelemesinin yanında kişinin güçlü taraflarını da incelemeye başlaması neticesinde psikolojik dayanıklılık ilgi görmeye başlamıştır. Ayrıca insanların duyguları ile söz konusu duyguların zihinde 
yorumlanarak yansıtılmaları açısından etkin rol oynadığı belirtilmiştir (Şahin ve Güçlü, 2018: 204).

Psikolojik dayanıklılık tanımlanması oldukça zor olan karmaşık bir kavramdır (Fletcher ve Sarkar, 2013: 13). Bu konuyla ilgili yapılan araştırmalarda psikolojik dayanıklılık kavramının çeşitli araştırmacılar tarafından benzer olarak tanımı yapılmıştır (Atan ve Ünver, 2019: 209). Söz konusu tanımların odağında ise değişimlere karşı olumlu bir uyum sağlamanın, güçlüklere karşı koymanın ve güçlüklerin üstesinden gelmenin yer aldığı belirlenmiştir (Fletcher ve Sarkar, 2013: 13). Psikolojik dayanıklılık, bir kişilik özelliği olup bireyin stresli durumları nasıl karşıladığını ve nasıl kontrol altına alabildiğini ifade eder (Saltık ve Kızılırmak, 2020: 66). Ayrıca psikolojik dayanıklılığın kendini adama, meydan okuma ve kontrol olmak üzere üç alt boyutu bulunmaktadır (Kobasa, 1979). Bunlardan kendini adama alt boyutu; bireyin aktif bir şekilde, gelişen olayların içerisine dâhil olması sayesinde gerçekleşen anlam ve amaç duygusu biçiminde ifade edilir (Maddi vd. 2006). Meydan okuma boyutu alt boyutu; kişinin değişime olan inancını belirtmektedir (Kamya, 2000). Kontrol alt boyutu ise yaşamdaki olaylarda bireyin kontrolü elinde tutmasıdır, güçsüzlüğü kabul etmemesi ve mücadele etmesidir şeklinde nitelendirilir (Maddi, 2004).

Güç durumlarla karşı karşıya kalındığında pes etmemek, dayanıklı olmak için bireyin herhangi bir nedene sahip olması gerekir. Bireyin hayatın anlamını arayarak ve bularak bu nedeni oluşturması mümkündür (Terzi, 2016). Hayatında herhangi bir anlama sahip olanların, başından geçen güçlükleri daha kolay bir şekilde aşabildikleri yine bu kişilerin psikolojik dayanıklılık düzeylerinin de fazla olduğu düşünülmektedir (Ekşi vd., 2018: 1699). Psikolojik dayanıklılık düzeyi fazla insanların ileriye yönelik umudu olan, kendilerine güven duyan, pozitif olarak iş hayatlarında da daha fazla başarı sağ layacakları düşünülmektedir (Üzüm ve Şenol, 2020: 458). Psikolojik dayanıklılık düzeyi yüksek insanların stres eşiğinin daha yüksek olduğu belirtilmektedir. Dolayısıyla bunlardan değişim, çatışma, kriz ve başka kritik koşullarda daha fazla motivasyon ve performans sergilemeleri beklenmektedir (Bitmiş vd., 2013). Söz konusu durum bireylere çalışma ve özel yaşamlarında kolaylık yaratır (Kavi ve Karakale, 2018: 73). Psikolojik dayanıklılık düzeyi yüksek çalışanların daha az gerginlik ve kaygı yaşayacakları ifade edilebilir. Ayrıca bunlar, organizasyonda karşılaştığı birtakım eylemleri örgütsel hayatın olması gereken bir sonucu şeklinde göreceklerdir (Erkutlu ve Soyumert, 2020: 5). Nitekim örgüt çalışanlarının psikolojik dayanıklılık düzeylerinde artış yaşanırsa bunların stresle, tükenmişlikle ve özellikle duygusal tükenmeyle mücadele etmeleri de kolay olur (Sezgin, 2012: 490-491).

Alanyazın incelendiğinde psikolojik dayanıklılık konusuyla ilgili olarak birtakım araştırmaların yapıldığı görülmektedir. Bu araştırmaların bazılarında 
duygusal zekânın (Büyükbayram vd., 2016: 34), örgütsel adaletsizliğin (Köse vd., 2018: 256), kişilik özelliklerinin (Polatcı vd., 2017: 566; Çavuşoğlu ve Yalçın, 2018: 62), iyimserliğin ve özgeci davranışın (Parmaksız, 2020: 293) psikolojik dayanıklılık üzerine etkisinin incelendiği belirlenmiştir. Diğer yandan alanyazındaki bazı araştırmalarda ise psikolojik dayanıklılığın iş tatmini (Kanbur vd., 2017: 133; Polatc1 vd., 2017: 566-567), örgütsel adalet (İslamoğlu ve Kirtulukoğlu, 2017: 33), duygu düzenleme (Şahin ve Güçlü, 2018: 212), örgütsel dışlanma (Köse vd., 2018: 256), örgütsel vatandaşlık davranışı (Kanbur vd., 2017: 133; Altan, 2019), işten ayrılma niyeti (Altan, 2019), yaşam doyumu (Ülker Tümlü ve Recepoğlu, 2013: 208; Kılınç vd., 2019: 115), stres yönetimi (Saltık ve Kız1lırmak, 2020: 65), mutluluk (Akbaba, 2020: 184-185) ve kayg1 (Baykal, 2020: 75) üzerine etkisinin ele alındığ1 tespit edilmiştir. Nitekim alanyazında psikolojik dayanıklılığın Covid-19 korkusu üzerine etkisini inceleyen herhangi bir araştırmaya rastlanılamamıştır. Böyle bir araştırmanın AVM çalışanları üzerinde gerçekleştirilmediği de görülmüş̧ür. Buradan hareketle araştırmada psikolojik dayanıklılık ve Covid-19 korkusu konuları bir arada ele alınmıştır. Araştırmada psikolojik dayanıklılığın Covid-19 korkusu üzerine etkisinin incelenmesi ve Kahramanmaraş'taki bir AVM'nin çalışanlarına uygulanmasının çalışmanın özgünlüğü açısından değerli olduğu düşünülmüştür.

$\mathrm{Bu}$ araştırmada öncelikle kavramsal çerçeve ayrıntılı olarak sunulmuştur. Sonrasında araştırmanın metodolojisine yer verilmiş ve araştırma verileri analiz edilerek yorumlanmıştır. En son olarak araştırma sonuç ve öneriler bölümüyle bitirilmiştir.

\section{KAVRAMSAL ÇERÇEVE}

Bu bölümde psikolojik dayanıklılık ve boyutları, Covid-19 korkusu ve boyutları kavramsal çerçeve kapsamında ayrıntılarıyla sunulmuştur.

\section{Psikolojik Dayanıklılık ve Boyutları}

Toplumsal bir varlık olan insanın, tabiatı gereğince birlikte yaşama becerisiyle donanmış bir şekilde hayata geldiği belirtilmektedir (Izgar vd., 2004). Birçok birey için hayata karşı güçlü durabilmek, birtakım zor durumlarla başa çıkabilmek ve sonrasında kalınan yerden devam edebilmek önemlidir (Kavi ve Karakale, 2018: 57). Başından geçen travmalar sonucunda bazı insanların ruh sağlıklarını yitirmeleri söz konusu olabilir. Yani depresyon, endişe ve kaygı gibi hastalıklar ile karşılaşmaları olasıdır. Böyle durumlardan kurtulmak ve iyileşmekte belirli bir süreci gerektirebilir. Bazı insanlara bakıldığında ise onların, geçirdikleri sarsıcı durumların olumsuzluklarından çok fazla etkilenmedikleri görülmektedir. Ayrıca yaşadıkları o kötü ruh halini kısa sürede atlatabilmeleri ve yaşamlarını kaldıkları noktadan sürdürmeleri de mümkündür (Doğan, 2015: 93). Bu açıdan insanları zor durumlardan koruyacak, zor 
durumların üstesinden başarıyla gelebilmelerinde yardımcı olacak donanım niteliğindeki psikolojik dayanıklılık konusu büyük önem taşımaktadır (Buz ve Genç, 2019: 624). Stresle ve zorluklarla başa çıkma kapasitesi (Buchecker ve Degenhardt, 2015) biçiminde nitelendirilen psikolojik dayanıklılığın, geçtiğimiz son 20 yılda davranış bilimleri alanındaki araştırmacı ile uzmanların deneysel araştırmalarında ve kuramsal analizlerinde görülmeye başladığı belirlenmiştir (Sezgin, 2009). Nitekim pozitif psikolojinin önem taşıyan konularından biri de psikolojik dayanıklılıktır (Kavi ve Karakale, 2018: 59). Özellikle pozitif psikolojide, olumlu kavramların incelenmesi gerekliliği belirtilmesi gereken en ciddi konu şeklindedir (Akbaba, 2020: 185). Nitekim insanlardaki bozukluklar, olumsuzluklar, eksik tarafların incelenmesinin olumlu ve güçlü tarafların incelenmesine ve geliştirilmesine neredeyse hiç firsat bırakmadığı görülmüştür (Akbaba, 2020: 180).

Psikolojik dayanıklılık ilk kez Kobasa tarafindan (1979), yılında ortaya çıkarılmışıı (Öztürk ve Erdem, 2020: 30). Psikolojik dayanıklılık, kişilerin olumsuz durumlar karşısında yaşamına yeniden devam edebilme kapasitesi ve gücü olarak ifade edilmektedir (Tambulut ve Eker, 2019: 150). Ayrıca kavramın ölçümünün ve tanımlanmasının tekrardan düşünülmesi gerekliliğine ilişkin bir anlayışın olduğu da söylenmektedir (Klag ve Bradley, 2004). Birtakım araştırmacıların psikolojik dayanıklılığı, kişilik özelliği şeklinde gördükleri belirtilmektedir. Diğer yandan birtakım araştırmacıların geliştirilebilen ve sonunda da kazanılan nitelikler biçiminde değerlendirdikleri görülmektedir (Kaba ve Keklik, 2016: 100). Psikolojik dayanıklılığın ileriye yönelik olumlu beklentileri ve pozitif sosyal ilişkileri gerektirdiği vurgulanmaktadır (Masten ve Reed, 2002). Psikolojik dayanıklılığın, çözüm odaklı mücadele etme ile sorunu kontrol altında tutmaya ilişkin tutumları içerdiği ifade edilmektedir (Folkman ve Lazarus, 1990). İnsanın sahip olduğu bazı bireysel koruyucu özelliklerin ve sosyal çevresinde bulunan koruyucu etmenlerin psikolojik dayanıklılı̆̆ın kazanılmasında ve geliştirilerek sürdürülmesinde etkili olduğu belirtilmektedir (Çetin vd., 2015: 82). Çok değişken içermesi sebebiyle psikolojik dayanıklılı̆̆ın ölçümüyle ilgili çeşitli araştırmaların gerçekleşmesi söz konusu olmuştur (Oktan, 2012). Araştırmalarda psikolojik dayanıklılığın çok boyutlu bir yapıya sahip olduğu görülmüsştür (Hjemdal vd., 2001). Bu doğrultuda psikolojik dayanıklılık boyutları aşağıda detaylı bir şekilde açıklanmaya çalışılmıştır.

Kendini Adama Boyutu: Kendini adama, şartlar ve durumlar ne kadar zor olursa olsun, bireyin duruma yabancılaşmadan ve kopmadan işine yoğunlaşmasını ifade etmektedir. Meraklı olmayı ve faal olmayı gerektirdiği belirtilmektedir (Maddi, 2013: 8). Kendini adamanın kendine inanma, hayata karşı ilgi duyma, kendi amaçlarının ve değerlerinin farkına varma, duygusal destek alma ile duygusal destek vermeye istekli olmayla meydana gelen güçlü bir gerçeklik duygusunu da yanında getirmesi söz konusudur (Kamya, 2000). 
Meydan Okuma Boyutu: Meydan okuma, durağan olmaktan çok değişime olan inancı ifade etmektedir (Holt vd., 1987). Bu özelliğe sahip insanlar bilgiye gayret gösterilmeden kolaylıkla ulaşılamadığını, güç durumlar ve bunların karşısında verilen gayretin ve zahmetin insanın gelişiminde etkili olduğunu farkındadırlar (Kobasa vd., 1982). Böyle insanlar ise etrafindakiler tarafindan kaynakları ve zamanı etkin olarak kullanan, içten, esnek, işleri kolaylaştıran ve sorun giderici insanlar olarak tanınırlar. Ayrıca değişen durumları etkili biçimde değerlendirme ve yorumlama becerisine sahip oldukları görülmektedir (Kobasa ve Puccetti, 1983).

Kontrol Boyutu: Kontrol, zorluklarla karşılaşıldığında kötü etkilenme yerine, olaylara istediği şekilde yön vereceğine inanma ve bu yönde davranmadır (Sezgin, 2012: 490-491). Bu boyutun olayların ve kişisel tepkilerin kontrol edilebilirliğine yönelik inançla ilişskili olduğu belirtilmektedir. Söz konusu inanca sahip insanların, stres oluşturan durumu kontrol edebileceklerini ve bu durumu kendi menfaatlerine dönüştürebileceklerini düşündükleri görülmektedir (Motan ve Gençöz, 2009). Daha açık ifade etmek gerekirse; böyle insanlar, olayların kendi halinde gidişine izin vermek ve meydana gelecek sonuçlara katlanmak yerine, mücadele ederek olumsuz sonuçları değiştirebilecekleri konusunda kendilerine güvenirler (Maddi vd., 2006).

Psikolojik dayanıklılık, insanın ruh halinin stres yaratan durumlarda bile sağlıklı olmasını sağladığı gibi (Williams, 2001), insanın yaşamında meydana gelen negatif durumlara yönelik kullandığı bir karşı koyma gücü şeklinde görülmektedir (Kobasa, 1979). Psikolojik dayanıklılığın stresin olumsuz sonuçlarını azaltan ve uyum sağlamayı kolay hale getiren bir nitelik olarak kendini göstermesi mümkündür (Jacelon, 1997). Psikolojik yönden dayanıklı olmanın güç bir durumu tehdit şeklinde algılamayı azaltması söz konusu olduğu gibi; etkili baş etme stratejilerinin kullanılmasını sağlayarak iyi olmaya etkisi bulunmaktadır (Saltık ve Kızılırmak, 2020: 54). Psikolojik dayanıklılı̆ıı, insanın sosyal kaynaklarını (arkadaş ve aile), bireysel kaynaklarını (hayata ilişkin gerçekçi bir yönelim, özgüven ve umut) ve sosyal yeterliliğini (yakın ilişki kurabilme yeteneği, dışadönüklük, kişilerarası ilişkilerde esneklik ve iletişim becerileri) aynı anda değerlendirmeye imkân tanıdığg görülmektedir (Friborg vd., 2003). Psikolojik dayanıklılıkta bir baş edebilme durumu söz konusudur. Birey psikolojik olarak dayanıklı ise daha mutlu ve sağlıklı bir yaşam sürecektir (Güngörmüş vd., 2015: 9-10). Ayrıca psikolojik dayanıklılığın geliştirilmesi, bireylere örgüt ortamının stresiyle başa çıkma yeteneği kazandırmaktadır (Lambert vd., 2003). 


\section{Covid-19 Korkusu ve Boyutları}

Dünyanın, tarihsel açıdan bakıldığında birçok zor durum ile karşı karşıya kaldığı görülmektedir. Karşılaşılan bu zor durumların başında ise küresel boyutta görülen salgın hastalıklar gelmektedir (Ceylan ve Özkan, 2020). Herhangi bir hastalık bulaşma yoluyla bir yerden başka bir yere yayılması, kısa sürede çok fazla vakada görülmesi ve son derece bulaşıcı olması durumunda "salgın" olarak tanımlanmaktadır (Aktaş, 2020: 109). Günümüz dünyası 2020 yılında çok derin etkileri olan bir salgın hastalığa maruz kalmıştır (Binbaşığlu, 2020: 73). Covid19 salgınının, dünyaya 2020 yılında damga vuran olaylardan birisi olduğu ifade edilebilir (Duygun, 2020: 233). Nitekim Covid-19'un bulaşıc1lık etkisiyle sağlığa verdiği zararın, dünyada son zamanlarda yaşanan en büyük salgın olarak ön plana çıktığ1 görülmektedir (Ünal, 2020: 14). Covid-19, henüz yeni keşfedilen ve insanlarda tanımlanmamış olan Covid-19'un yol açtığı bulaşıcı bir hastalık şeklinde nitelendirilir. Bu hastalık 2019 yılının Aralık ayında Çin'in Wuhan kentinde ortaya çıkmış olup, günümüzde hemen hemen bütün dünyadaki ülkeleri etkisi altına alan bir salgın haline gelmiştir (Jiang vd., 2020). Bu salgın, Çin'de ortaya çıktıktan iki ay gibi kısa bir süre sonra büyük ölçüde tüm ülkelere yayılmaya başlamıştır (Aydın ve Doğan, 2020: 105). Beklenmedik biçimde gelişen ve hızla yayılan bu salgın, bütün dünya ülkelerinde sosyal ilişkiler, ekonomik, kültürel ve siyasi yani insan unsurunun bulunduğu her alanda etki yaratmıştır (Yıldırımvuran vd., 2020: 53). Yaşamın neredeyse her alanında çok ciddi problemlere neden olan bu salgının, her yönüyle incelenmesi büyük önem taşımaktadır (Paksoy, 2020: 143-144).

Covid-19, hayvanlardan insanlara mutasyon geçirerek bulaşan ve sonrasında insandan insana yayılan bir virüstür (Özdemir, 2020: 547) şeklinde tanımlanmaktadır. Özelliğinden dolayı neredeyse tüm ülkeler bundan korunmak adına olabildiğince sert, bir dizi fakat olması gereken tedbirler ile kurallar almaya mecbur kalmışlardır (Aydın ve Doğan, 2020: 94-95). Bu salgına engel olabilmek noktasında ülkelerden ülkelere turistik faaliyetler ve girişler-çıkışlar yasaklanmıştır (Şit ve Telek, 2020: 3). Örgüt çalışanlarının aynı zaman diliminde işyerinde bulunmalarının artık iş sağlığ 1 ve güvenliği açısından tehdit yaratmaya başlaması, kısmi çalışma ve esnek çalışma gibi istihdam türlerinin ön plana çıkmasında etkili olmuştur (Bulut ve Pınar, 2020: 219). Ayrıca henüz doğrudan Covid-19'u tedavi edebilecek aşının veya ilacın da üretiminin gerçekleştiği söylenemez (Paksoy, 2020: 136). Covid-19 salgınına çare bulunamamış olması diğer bir taraftan bireylerin endişe ve korkuya düşmesine sebep olmuş, artan bu endişe ile korku bireylerin davranışlarına yansımıştır (Paksoy, 2020: 135). Bununla birlikte Covid-19 korkusunun psikolojik faktörler boyutu, psikosomatik faktörler boyutu, ekonomik faktörler boyutu ve sosyal faktörler boyutu bulunmaktadır. Covid-19 korkusu boyutları, araştırmamızda kullanılan Covid-19 Ölçeği'nden Arpacı vd. (2020) hareketle şu şekilde açıklanabilir. 
Psikolojik Faktörler Boyutu: Covid-19 korkusunun birçok insanda psikolojik açıdan rahatsızlık meydana getirdiği belirtilebilir. Bu salgın sürecinde Covid-19'a her an yakalanma riskiyle karşı karşıya olan insanın korku duyması, endişe yaşaması, gerilim içerisinde olması gibi durumların insanı psikolojik açıdan yıpratması mümkündür.

Psiko-Somatik Faktörler Boyutu: Covid-19 salgını sürecinde yaşanan psikolojik rahatsızlıkların zamanla fiziksel rahatsızlıklara yol açtığı belirtilebilir. $\mathrm{Bu}$ durumda insanda baş ağrısı, mide rahatsızlığı, üşüme, cilt hastalıkları vb. görülebilir. Böyle hastalıkların ise insan hayatını zorlaştırması söz konusudur.

Ekonomik Faktörler Boyutu: İnsan hayatı için önem taşıyan birtakım ihtiyaçlar (yiyecek, içecek, temizlik vb.) bulunmaktadır. Covid-19 salgını ve bunun etkilerinin ne zaman biteceğinin bilinememesi insan ihtiyaçlarıyla ilgili korkuyu bu süreçte daha da tetiklemektedir.

Sosyal Faktörler Boyutu: Covid-19'un yayılma hızı, insanın olduğu sosyal ortamlarda özellikle kendini göstermektedir. Bu noktada Covid-19'a yakalanma korkusu nedeniyle sosyal bir varlık olan insanın, etrafinda bulunan başka insanlardan uzaklaştığı görülebilir.

Covid-19 salgınıyla karşılaşıncaya kadar, dünyadaki hiçbir büyük güç küreselleşmeye böylesine etkin olarak meydan okumamış ya da bunu aksi yöne çevirmemiştir (Niewiadomski, 2020). Covid-19 salgınının değerleri sorgulatan, örgütlere ilişkin güven duygusunda sarsintı yaratan hem ekonomik hem toplumsal düzen üzerinde ağır bir etki oluşturan, korku ile belirsizliğin hükmettiği evrensel nitelikte varoluşsal bir kriz meydana getirdiği görülmüştür (Bozkurt vd., 2020: 305). Covid-19 sosyo-psikolojik ve ekonomik olduğu gibi birçok alanda yıkıma neden olmuştur (Aydın ve Doğan, 2020: 108). Bunun sonucunda bireylerin psikolojik ve ekonomik yönden çökme noktasına geldikleri görülmüştür (Binbaşığlu, 2020: 82). Covid-19 salgının, dünya çapında etkisini göstermeye başlamasıyla birlikte küresel ekonomi düşüş yaşamış, dünya dış ticaretinde önemli bir azalma yaşanmıştır. Bu bağlamda ülkelerin ihracat ile ithalat gerçekleştiremeyecek bir hale geldikleri görülmüştür (Kaya, 2020: 233). Covid-19 küresel çapta işletmelerin kapanmasında, tüketimde azalma yaşanmasında, üretimin durmasında ve işsizlik oranının yükselişe geçmesinde etkili olmuştur (Özdemir, 2020: 547). Covid-19'un kısa bir zamanda bütün dünyada etki yaratan küresel nitelikteki bir salgına dönüşmesi, istisnasız tüm ülkelere ani yeni yükler veya yükümlülükler getirmiştir (Boyac1, 2020: 60). Sonuçta salgına karşı mücadele etmek adına mikro düzeyden makro düzeye kadar, her alanda iş birliği ile sorumluluğa ihtiyaç duyulduğu görülmektedir (Aydın ve Doğan, 2020: 108). 


\section{PSİKOLOJİK DAYANIKLILIK ile COVID-19 KORKUSU İLİŞKİSI ve ILGGILİ HIPOTEZLER}

Son yıllarda dünyada birçok değişim, gelişim, yenilik yaşanmakta bunlarında insan ve örgüt yaşamını doğrudan ve dolaylı olarak etkilediği görülmektedir. Bunların meydana gelmesinde rolü olanlardan birinin belki de en önemlisinin insan olduğu dikkat çekmektedir. İnsan, özel ve çalışma hayatında birçok olumlu ve olumsuz durumla karşılaşmaktadır. İnsan hayatı için olumlu durumlar yaşamı kolaylaştırırken, olumsuz durumların yaşamı çıkmaza sürüklemesi kaçınılmazdır. İnsanın özellikle çalışma hayatına ve buradakilere faydalı olmak için verdiği uğraşlarda psikolojik dayanıklılık düzeyinin önem taşıdığ 1 unutulmamalıdır. Diğer taraftan küresel dünyada yaşanan başka durumlarında örgütleri ve çalışanları bir şekilde etkilediği görülmektedir. Örgütlerin ve çalışanların karşı karşıya kaldığ 1 ve mücadele etmekte oldukça zorlandığ 1 durumlardan biri de Covid-19 salgınıdır. Covid-19 salgınının son bir yıldır neredeyse bütün dünyayı etkisi altına alarak örgütleri ve çalışanları yaşam ve ölüm arasındaki o ince çizgi de kritik derecede etkilediği görülmüştür. Örgütün ve çalışanların hayatını tehdit eden Covid-19 salgını, çalışanları her yönden olduğu gibi psikolojik yönden de etkilemiştir. $\mathrm{Bu}$ bakımdan psikolojik dayanıklılık düzeyi yüksek çalışanlara sahip örgütlerin, Covid-19 salgınının olumsuz etkilerine karşı mücadelede daha etkin olacakları düşünülmektedir. Alanyazındaki araştırmaların bazılarında psikolojik dayanıklılığın iş doyumu (Kanbur vd., 2017: 133; Polatc1 vd., 2017: 566-567), örgütsel adalet (İslamoğlu ve Kirtulukoğlu, 2017: 33), duygu düzenleme (Şahin ve Güçlü, 2018: 212), örgütsel dışlanma (Köse vd., 2018: 256), örgütsel vatandaşlık davranışı (Kanbur vd., 2017: 133; Altan, 2019), işten ayrilma niyeti (Altan, 2019), yaşam doyumu (Ülker Tümlü ve Recepoğlu, 2013: 208; Kılınç vd., 2019: 115), stres yönetimi (Saltık ve Kizılırmak, 2020: 65), mutluluk (Yılmaz Akbaba, 2020: 184-185) ve kayg1 (Baykal, 2020: 75) üzerine etkisinin ele alındığı belirlenmiştir. Diğer taraftan birtakım araştırmalarda ise duygusal zekânın (Büyükbayram vd., 2016: 34), örgütsel adaletsizliğin (Köse vd., 2018: 256), kişilik özelliklerinin (Polatc1 vd., 2017: 566; Çavuşoğlu ve Yalçın, 2018: 62), iyimserliğin ve özgeci davranışın (Parmaksız, 2020: 293) psikolojik dayanıklılık üzerine etkisinin incelendiği görülmüştür. Nitekim yerli ve yabancı araştırmalarda psikolojik dayanıklılığın Covid-19 korkusu üzerine etkisini ele alan herhangi bir çalışmaya rastlanılamamıştır. $\mathrm{Bu}$ durum alan araştırmasının gerçekleştirilmesinde etkili olmuştur.

Yukarıdaki bilgilerden hareketle bu araştırmada, psikolojik dayanıklılık ve boyutlarının (kendini adama, meydan okuma ve kontrol) Covid-19 korkusu ve boyutlarını (psikolojik faktörler, psiko-somatik faktörler, ekonomik faktörler ve sosyal faktörler) etkileyeceği varsayımında bulunulmuş ve ilgili hipotezler aşağıda kurulmuştur: 
H1. Kendini adama psikolojik faktörleri negatif yönde etkiler.

H2. Meydan okuma psikolojik faktörleri negatif yönde etkiler.

H3. Kontrol psikolojik faktörleri negatif yönde etkiler.

H4. Kendini adama psiko-somatik faktörleri negatif yönde etkiler.

H5. Meydan okuma psiko-somatik faktörleri negatif yönde etkiler.

H6. Kontrol psiko-somatik faktörleri negatif yönde etkiler.

H7. Kendini adama ekonomik faktörleri negatif yönde etkiler.

H8. Meydan okuma ekonomik faktörleri negatif yönde etkiler.

H9. Kontrol ekonomik faktörleri negatif yönde etkiler.

H10. Kendini adama sosyal faktörleri negatif yönde etkiler.

H11. Meydan okuma sosyal faktörleri negatif yönde etkiler.

H12. Kontrol sosyal faktörleri negatif yönde etkiler.

\section{ARAȘTIRMANIN METODOLOJISI}

$\mathrm{Bu}$ bölümde araştırmanın amacı, önemi, sınırlılıkları, yöntemi, evreni ve örneklemi, etik kurul onay1, hipotezleri ve modeli, verilerin analizi ve bu analizlerin sonuçları detaylı olarak sunulmuştur.

\section{Araştırmanın Amacı}

$\mathrm{Bu}$ araştırmanın amacı, psikolojik dayanıklılık ve boyutlarının (kendini adama, meydan okuma ve kontrol) Covid-19 korkusu ve boyutları (psikolojik faktörler, psiko-somatik faktörler, ekonomik faktörler ve sosyal faktörler) üzerine etkisini incelemektir.

\section{Araştırmanın Önemi}

Alanyazın incelendiğinde psikolojik dayanıklılık ve Covid-19 korkusu konularıyla ilgili birtakım teorik ve deneysel araştırmaların yapıldığı görülmüştür. Bu alan araştırmasında psikolojik dayanıklılık ve Covid-19 korkusu konuları bir arada ele alınmıştır. Yapılan bu araştırmayla psikolojik dayanıklılığın Covid-19 korkusu üzerine etkisi incelenmiştir. Ayrıca araştırma, Kahramanmaraş'taki bir AVM'nin çalışanları üzerinde gerçekleştirilmiştir. Bütün bunların araştırmayı öncekilerden farklı kılması, araştırmanın kapsamlı bir şekilde değerlendirilmesi ve yazına fayda sağlaması açısından önem taşıdığı düşünülmüştür.

\section{Araştırmanın Sınırlılıkları}

$\mathrm{Bu}$ araştırmanın birtakım sınırlılıkları bulunmaktadır. Araştırmanın en büyük sınırlılığını tüm dünyayı etkileyen Covid-19 salgını oluşturmuştur. Covid-19'un etkisiyle birçok AVM tam zamanlı ve yarı zamanlı kapalı duruma gelmiş, çalışanlarına izin vermiş, çalışan sayısını azaltmak zorunda kalmış ve 
çalışanlarını işten çıkarmıştır. Diğer taraftan araştırmanın yalnızca bir AVM'de gerçekleştirilmesi, AVM çalışanlarının anket formundaki ifadeleri algıma dereceleri ve cevaplamadaki içtenlikleri gibi sınırlılıklarda mevcuttur. Araştırmaya AVM çalışanlarının sosyal mesafe nedeniyle çekimser kalmaları, kısıtlama nedeniyle hafta içi sabah ve akşam belirli saatlerde katılmaları, araştırmanın belli bir zaman dönemini kapsaması da (1 aylık süre) bu sınırlılıklar arasinda yer almaktadır.

\section{Araştırmanın Yöntemi, Evreni ve Örneklemi}

Araştırmada, AVM çalışanlarının psikolojik dayanıklılık ve Covid-19 korkusuyla ilgili fikirleri ölçülmeye çalışılmıştır. Araştırma verilerini toplamak için anket tekniği kullanılmıştır. Araştırma anket formu üç bölümden meydana gelmektedir. Anket formunun birinci bölümünde, AVM çalışanlarının demografik özelliklerini ölçmeye yönelik 7 soru hazırlanmıştır. Anket formunun ikinci bölümündeki psikolojik dayanıkl1lık ve üçüncü bölümündeki Covid-19 korkusuyla ilgili ifadeleri ölçmede 5'li Likert Ölçeği'nden “1=Kesinlikle Kat1lmiyorum, 2=Katılmıyorum, 3=Kararsizım, 4=Kat1lıyorum, 5=Kesinlikle Katılıyorum" faydalanılmıştır. Bunların dışında araştırmanın evreni ve örneklemi konusunda da bazı açıklamalarda bulunmanın faydalı olacağı düşünülmektedir. Evren, tespit edilen amaçlar doğrultusunda belirlenen birimler grubunun tümü olarak tanımlanmaktadır (Nakip, 2006: 196). Bu araştırmanın evrenini bir AVM'nin yaklaşık 500 çalışanı meydana getirmiştir. Bilimsel çalışmalarda evrenin bütününe ulaşılabileceği gibi belirli yöntemler ile evreni temsil edebilecek örneklemin seçilmesi de mümkün olabilir (Karasar, 2005: 127). Örneklemi de evreni en iyi temsil eden ve belli bir yönteme göre evrenden seçilen alt grup olarak ifade edilmektedir (Nakip, 2006: 196). Araştırmanın örneklemini bu AVM'nin 169 çalışanı oluşturmuş̧tur. Ayrıca alan araştırmasında kullanılan ölçekler ise şu şekildedir:

Psikolojik Dayanıklılık Ölçeği: Işık (2016), tarafından geliştirilmiştir. Psikolojik Dayanıklılık Ölçeği toplam 21 ifade ve 3 boyuttan oluşmaktadır. Psikolojik Dayanıklılık Ölçeği'nin kendini adama boyutu 7 ifade, meydan okuma boyutu 7 ifade ve kontrol boyutu 7 ifadedir. Psikolojik Dayanıklılık Ölçeği’'ndeki ifadelerin bazıları şu şekildedir; "Çalışmaktan çok keyif duyuyorum", "Her yeni deneyimin yaşamımı zenginleştirdiğini düşünüyorum" ve Kaderimi değiştirebileceğime inanırım”.

Covid-19 Korkusu Ölçeği: Arpacı vd. (2020) tarafından geliştirilmiştir. Covid19 Korkusu Ölçeği toplam 20 ifade ve 4 boyuttan meydana gelmektedir. Covid19 Korkusu Ölçeği'nin psikolojik faktörler boyutu 6 ifade, psiko-somatik faktörler boyutu 5 ifade, ekonomik faktörler boyutu 4 ifade ve sosyal faktörler boyutu 5 ifadedir. Covid-19 Korkusu Ölçeği'ndeki ifadelerin bazıları şu 
şekildedir; "Koronavirüse yakalanma korkusu beni çok endişelendiriyor", "Koronavirüs korkusundan ciddi mide ağrıları yaşıyorum", Koronavirüs salgını nedeniyle gıda arzı sıkıntısı ihtimali ben de endişye yaratıyor" ve "Koronavirüs salgınından sonra, öksüren insanları gördüğümde kendimi aşırı derecede endişeli hissediyorum".

\section{Araştırmanın Etik Kurul Onayı}

$\mathrm{Bu}$ araştırmanın anket formları uygulanmadan önce, Kahramanmaraş Sütçü İmam Üniversitesi Sosyal ve Beşerî Bilimler Etik Kurul Başvuru Formu doldurulmuş ve Etik Kurul İzni alınmıştır. Sonrasında AVM çalışanlarından bu anket formlarını gönüllülük esasına dayanarak doldurmaları istenmiştir. Araştırmaya katılan AVM çalışanlarının kimlikleri gizli tutulmuştur. Araştırma verileri tamamen bilimsel amaçlı kullanılmış ve üçüncü şahıslarla paylaşılmamıştır.

\section{Araştırmanın Hipotezleri ve Modeli}

Psikolojik dayanıklılık ile Covid-19 korkusu ilişkisi ve ilgili hipotezler bölümünde bu araştırmanın hipotezleri kurulmuştur. Araştırmada psikolojik dayanıklılığın (kendini adama, meydan okuma ve kontrol) Covid-19 korkusu (psikolojik faktörler, psiko-somatik faktörler, ekonomik faktörler ve sosyal faktörler) üzerine etkisi Şekil 1'de model oluşturularak gösterilmiştir.

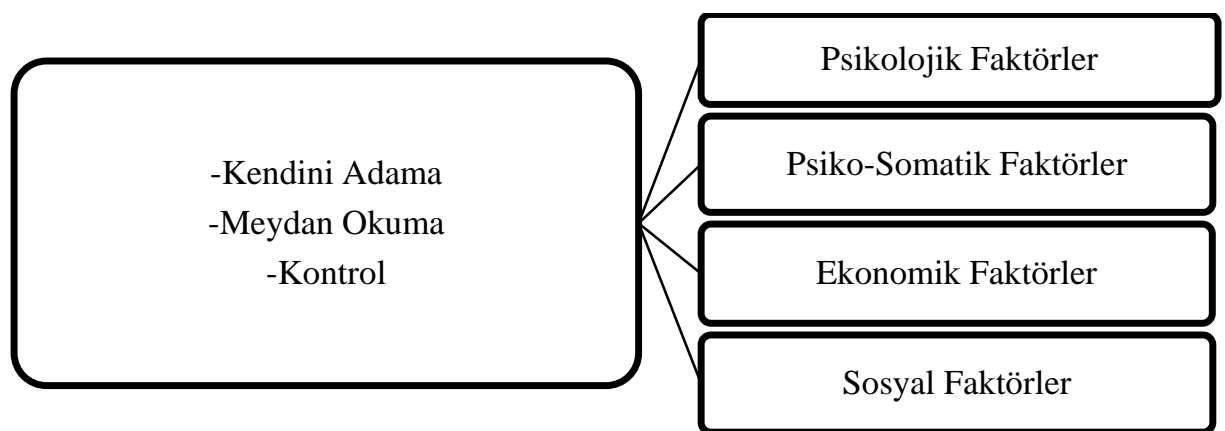

Şekil 1. Araştırma Modeli: Psikolojik Dayanıklılık, Covid-19 Korkusu Verilerin Analizi İlișkisi

$\mathrm{Bu}$ araştırmanın verilerini analiz etmek için SPSS 25.0 yazılım programı kullanılmıştır. Araştırma verileri öncelikle frekans, güvenirlik, korelasyon ve regresyon analiziyle test edilmiş sonrasında bunların sonuçları sunulmuş ve yorumları yapılmıştır. 


\section{ARAŞTIRMANIN BULGULARI}

$\mathrm{Bu}$ bölümde, araştırmanın demografik ve temel bulguları kapsamında istatistiki analizler yapılmış ve analizlerin bulgularına ilişkin yorumlarda bulunulmuştur.

\section{Frekans Analizi ve Sonuçları}

Araştırmada demografik özelliklere (cinsiyet, medeni durum, yaş aralığ 1 , eğitim durumu, pozisyon, çalışma süresi ve aylık gelir) ilişkin sorular frekans analiziyle test edilmiş ve sonuçları Tablo 1'de gösterilmiştir.

Tablo 1: Frekans Analizi ve Sonuçları

\begin{tabular}{|c|c|c|c|}
\hline & Kategoriler & $\mathrm{N}$ & $\%$ \\
\hline \multirow[t]{2}{*}{ Cinsiyet } & Bay & 74 & 43.8 \\
\hline & Bayan & 95 & 56.2 \\
\hline \multirow[t]{2}{*}{ Medeni Durum } & Evli & 88 & 52.1 \\
\hline & Bekar & 81 & 47.9 \\
\hline \multirow[t]{6}{*}{ Yaş Aralığ } & 25 ve Alt1 & 39 & 23.1 \\
\hline & $26-30$ & 46 & 27.2 \\
\hline & $31-35$ & 26 & 15.4 \\
\hline & $36-40$ & 27 & 16.0 \\
\hline & $41-45$ & 14 & 8.3 \\
\hline & 46 ve Üzeri & 17 & 10.1 \\
\hline \multirow[t]{5}{*}{ Eğitim Durumu } & Lise & 73 & 43.2 \\
\hline & Ön Lisans & 35 & 20.7 \\
\hline & Lisans & 30 & 17.8 \\
\hline & Yüksek Lisans & 7 & 4.1 \\
\hline & Diğer & 24 & 14.2 \\
\hline \multirow[t]{5}{*}{ Pozisyon } & Personel & 127 & 75.1 \\
\hline & Bölüm Yöneticisi & 9 & 5.3 \\
\hline & Müdür Yardımcısı & 4 & 2.4 \\
\hline & Müdür & 14 & 8.3 \\
\hline & Diğer & 15 & 8.9 \\
\hline \multirow[t]{5}{*}{ Çalışma Süresi } & 1 Yildan Az & 25 & 14.8 \\
\hline & 1-5 Yil & 82 & 48.5 \\
\hline & $6-10$ Yil & 35 & 20.7 \\
\hline & 11-15 Y1l & 17 & 10.1 \\
\hline & 16 Y1l ve Üzeri & 10 & 5.9 \\
\hline \multirow[t]{4}{*}{ Aylık Gelir (TL) } & $2000-2500$ & 64 & 37.9 \\
\hline & 2501-3000 & 43 & 25.4 \\
\hline & $3001-3500$ & 34 & 20.1 \\
\hline & 3501 ve Üzeri & 28 & 16.6 \\
\hline
\end{tabular}

Tablo 1'de görüldüğü üzere; AVM çalışanlarının cinsiyete göre dağılımları incelendiğinde 95'ini (\%56.2) bayanların oluş̧urduğu görülmüştür. Araştırmaya katılan AVM çalışanlarından 74'ünü $(\% 43.8)$ bayların meydana getirdiği 
saptanmıştır. $\mathrm{Bu}$ durum araştırmaya katılanların çoğunluğunu bayanların oluşturduğunu göstermektedir.

Araştırmada katılımcıların medeni duruma göre dağılımları incelendiğinde 88'ini (\%52.1) evli, geriye kalan 81'ini (\%47.9) bekârların meydana getirdiği belirlenmiştir.

Araştırmada 26-30 yaş aralığıyla 46 (\%27.2), 25 ve altı yaş aralığıyla 39 (\%23.1), 36-40 yaş aralığıyla 27 (\%16.0), 31-35 yaş aralığıyla $26(\% 15.4), 46$ ve üzeri yaş aralığıyla 17 (\%10.1), 41-45 yaş aralığıyla 14 (\%8.3) AVM çalışanının belirli yaş aralıklarına göre dağılım gösterdiği tespit edilmiştir.

Araştırmaya katılanların eğitim durumu incelendiğinde 73 (\%43.2) AVM çalışanının lise mezunu olduğu görülürken, 7 (\%4.1) AVM çalışanın ise yüksek lisans mezunu olduğu saptanmıştır.

AVM çalışanlarının pozisyona göre dağılımı incelendiğinde 4'ünü (\%2.4) müdür yardımcısının oluşturduğu belirlenmiştir. $\mathrm{Bu}$ durum araştırmaya katılan AVM çalışanlarından müdür yardımcısı olanların sayıca en az olduğunu ortaya koymaktadır.

Araştırmada, 16 yıl ve üzeri çalışma süresiyle 10 (\%5.9), 11-15 yıl çalışma süresiyle 17 (\%10.1), 1 yıldan az çalışma süresiyle 25 (\%14.8), 6-10 yıl çalışma süresiyle 35 (\%20.7) ve 1-5 yıl çalışma süresiyle $82(\% 48.5)$ katılımcının belirli çalışma süresine göre dağ 11 ım gösterdiği tespit edilmiştir.

Araştırmada 2000-2500 (TL) aylık gelirle 64 (\%37.9) AVM çalışanının örneklemin en düşük gelir düzeyine sahip olduğu görülmüsstür. AVM çalışanlarından 3501 ve üzeri (TL) aylık gelirle 28 (\%16.6) katılımcının örneklemin en yüksek gelir düzeyine sahip olduğu saptanmıştır.

\section{Güvenirlik Analizi ve Sonuçları}

Güvenilir bir test veya ölçek, benzer şartlarda tekrar uygulandığında benzer sonuçlar vermektedir (Altunışık vd., 2010: 122), şeklinde ifade edilmektedir. Cronbach's Alpha'nın $(\alpha)$ en yaygın olarak kullanılan içsel güvenirlik indeksi olduğu belirtilmektedir. Bu indeks değişkenler arasındaki ortalama korelasyonu esas alıp, bir ölçekteki değişkenlerin iç tutarlığını ölçmektedir (Bayram, 2009: 194). Cronbach’s Alpha ( $\alpha$ ) katsayısına bağlı olarak ölçeğin güvenirliğinin şu şekilde yorumlandığı görülmektedir (Kayış, 2008: 405); $0.00 \leq \alpha<0.40$ ölçeğin güvenilir olmadığını; $0.40 \leq \alpha<0.60$ ölçeğin güvenirliğinin düşük olduğunu; $0.60 \leq \alpha<0.80$ ölçeğin yeterince güvenilir olduğunu ve $0.80 \leq \alpha<1.00$ ise ölçek yüksek düzeyde güvenilirdir.

Tablo 2. Güvenirlik Analizi ve Sonuçları

\begin{tabular}{lcc}
\hline Bovutlar & Cronbach’s Alpha $(\alpha)$ & İfade Savısı \\
\hline Psikoloiik Davanıklılık & & 7 \\
Kendini Adama & .735 & 7 \\
Meydan Okuma & .865 & 7 \\
Kontrol & .650 &
\end{tabular}




\begin{tabular}{lll} 
Covid-19 Korkusu & & \\
Psikoloiik Faktörler & .847 & 6 \\
Psiko-Somatik Faktörler & .959 & 5 \\
Ekonomik Faktörler & .907 & 4 \\
Sosyal Faktörler & .904 & 5 \\
\hline
\end{tabular}

Tablo 2'deki görüldüğü üzere; Cronbach's Alpha $(\alpha)$ değerlerine göre; kendini adama boyutu (.735), meydan okuma boyutu (.865), kontrol boyutu (.650), psikolojik faktörler boyutu (.847), psiko-somatik faktörler boyutu (.959), ekonomik faktörler boyutu (.907) ve sosyal faktörler boyutu (.904) olarak tespit edilmiştir. Elde edilen bu değerler araştırmada kullanılan ölçeklerin güvenilir düzeyde olduğunu ortaya koymaktadır.

\section{Araştırmanın Temel Bulguları}

Araştırmanın temel bulguları kapsamında korelasyon analizi ve regresyon analizi yapılmış ve bu analizlerin sonuçları yorumlanmaya çalışılmıştır.

\section{Korelasyon Analizi ve Sonuçları}

$\mathrm{Bu}$ çalışmada, değişkenler arasındaki ilişkiyi belirlemek için korelasyon analizi yapılmıştır. Korelasyon analizinin, tahmin ile kriter değişkenleri arasındaki ilginin derecesini ve yönünü tespit etmeyi amaçladığı belirtilmektedir (Kurtuluş, 2004: 329). Ayrıca korelasyon katsayısının, iki sürekli değişken arasındaki ilişkinin gücü ile yönü konusunda bilgi verdiği, katsayının $(-1)$ ve $(+1)$ arasında değiştiği ifade edilmektedir (Field, 2009). Bu araştırmanın korelasyon analizi ve sonuçları aşağıda Tablo 3 'te gösterilmiştir.

Tablo 3. Korelasyon Analizi ve Sonuçları

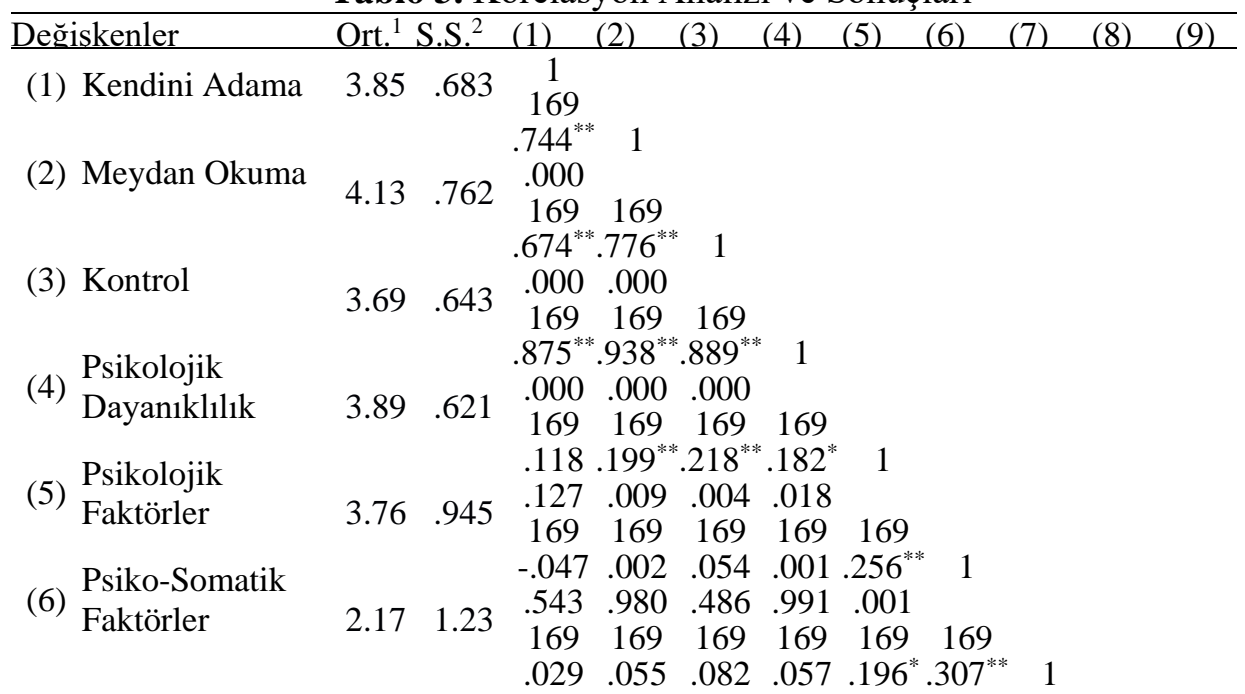


(7) Ekonomik
Faktörler

$\begin{array}{lllllll}.704 & .477 & .287 & .462 & .011 & .000\end{array}$

$\begin{array}{lllllllll}2.71 & 1.22 & 169 & 169 & 169 & 169 & 169 & 169 & 169\end{array}$

$\begin{array}{lllll}055 & 027 & 053 & 035 & 0589^{* *} .226^{* *} .563^{* *}\end{array}$

(8) Sosyal Faktörler

3.541 .10

$\begin{array}{llllllll}.481 & .732 & .495 & .655 & .000 & .003 & .000\end{array}$

(9) Covid-19

$\begin{array}{llllllll}169 & 169 & 169 & 169 & 169 & 169 & 169 & 169\end{array}$

(9) Korkusu

.053. 100 . 146 $14097.665^{* *} .668^{* *} .707^{* *} .763^{* *} 1$

$\begin{array}{lllllllllll}3.10 & .779 & .493 & .194 & .058 & .209 & .000 & .000 & .000 & .000 & \\ & 169 & 169 & 169 & 169 & 169 & 169 & 169 & 169 & 169\end{array}$

${ }^{*}$. Correlation is significant at the 0.05 level (2-tailed). ${ }^{* *}$. Correlation is significant at the 0.01 level (2-tailed).

Tablo 3'teki görüldüğ̈̈ üzere; Kendini adamanın psikolojik faktörler $(\mathrm{r}=.118 ; \mathrm{p}>, 0.05)$, psiko-somatik faktörler $(\mathrm{r}=-.047 ; \mathrm{p}>, 0.05)$, ekonomik faktörler $(\mathrm{r}=.029 ; \mathrm{p}>, 0.05)$, sosyal faktörler $(\mathrm{r}=.055 ; \mathrm{p}>, 0.05)$ ile herhangi bir anlamlı ilişkiye sahip olmadığı görülmüştür.

Meydan okumanın psikolojik faktörler $(\mathrm{r}=.199 ; \mathrm{p}<, 0.05)$ ile pozitif anlamlı bir ilişkiye sahip olduğu saptanmıştır. Fakat meydan okumanın psiko-somatik faktörler ( $\mathrm{r}=.002 ; \mathrm{p}>, 0.05)$, ekonomik faktörler ( $\mathrm{r}=.055 ; \mathrm{p}>, 0.05)$, sosyal faktörler $(\mathrm{r}=.027 ; \mathrm{p}>, 0.05)$ ile herhangi bir anlamlı ilişkiye sahip olmadığ

Kontrolün psikolojik faktörler $(\mathrm{r}=.218 ; \mathrm{p}<, 0.01)$ ile pozitif anlamlı bir ilişkiye sahip olduğu tespit edilmiştir. Ancak kontrolün psiko-somatik faktörler $(\mathrm{r}=.054 ; \mathrm{p}>, 0.05)$, ekonomik faktörler $(\mathrm{r}=.082 ; \mathrm{p}>, 0.05)$, sosyal faktörler $(\mathrm{r}=.053 ; \mathrm{p}>, 0.05)$ ile herhangi bir anlamlı ilişkiye sahip olmadığı görülmüştür.

Genel olarak ise psikolojik dayanıklılı̆ğn Covid-19 korkusu ( $\mathrm{r}=.097 ; \mathrm{p}>, 0.05)$ ile herhangi bir anlamlı ilişkiye sahip olmadığı saptanmıştır.

\section{Regresyon Analizi ve Sonuçları}

$\mathrm{Bu}$ çalışmanın ana hipotezleri test etmek için regresyon analizi yapılmıştır. Basit regresyon analizinin, bağımlı değişken tek bağımsız değişken tek olduğunda uygulandığı görülmektedir. Regresyon analizinin ise bağımlı değişken tek bağımsız değişken iki veya daha çok olduğunda yapıldığı belirtilmektedir (Büyüköztürk, 2009: 216). Bu araştırmanın regresyon analizi ve sonuçları aşağıdaki tablolarda sunulmuştur.

Çalışmada H1. (Kendini adama psikolojik faktörleri negatif yönde etkiler), H2. (Meydan okuma psikolojik faktörleri negatif yönde etkiler), H3. (Kontrol psikolojik faktörleri negatif yönde etkiler) test etmek için regresyon analizi yapılmış ve sonuçları Tablo 4'te gösterilmiştir.

Tablo 4. Kendini Adama, Meydan Okuma ve Kontrolün Psikolojik Faktörleri Etkilemesine İlişkin Regresyon Analizi Sonuçları

\begin{tabular}{lcccccccc}
\hline \multicolumn{10}{c}{ Bağımlı Değișken: Psikolojik Faktörler } \\
\hline Model & B & $\begin{array}{c}\text { Standart } \\
\text { Hata }\end{array}$ & $\beta$ & t & p. & F & $\mathrm{R}^{2}$ & $\Delta \mathrm{R}^{2}$ \\
\hline
\end{tabular}




\begin{tabular}{lccccc}
\hline Sabit & 2.63 & .452 & & 5.83 & .000 \\
Kendini Adama & -.150 & .161 & -.108 & -.931 & .353 \\
Meydan Okuma & .168 & .169 & .135 & .993 & .322 \\
Kontrol & .273 & .181 & .186 & 1.50 & .133 \\
\hline
\end{tabular}

Tablo 4'te görüldüğü üzere; Kendini Adama (H1) ( $\beta=-.108 ; \mathrm{p}>0,05)$, meydan okuma (H2) $(\beta=.135 ; \mathrm{p}>0,05)$ ve kontrol $(\mathrm{H} 3)$ 'ün $(\beta=.186 ; \mathrm{p}>0,05)$ psikolojik faktörleri etkilemediği görülmüştür. Bu sonuçlara göre (H1), (H2) ve (H3) reddedilmiştir.

Araştırmada H4. (Kendini adama psiko-somatik faktörleri negatif yönde etkiler), H5. (Meydan okuma psiko-somatik faktörleri negatif yönde etkiler), H6. (Kontrol psiko-somatik faktörleri negatif yönde etkiler) test etmek için regresyon analizi yapılmış ve sonuçları Tablo 5'te gösterilmiştir.

Tablo 5: Kendini Adama, Meydan Okuma ve Kontrolün Psiko-Somatik Faktörleri Etkilemesine İlişkin Regresyon Analizi Sonuçları

\begin{tabular}{lcccccccc}
\hline \multicolumn{1}{c}{ Bağıml Değisken: Psiko-Somatik Faktörler } \\
\hline \multirow{2}{c}{ Model } & $\mathrm{B}$ & $\begin{array}{c}\text { Standart } \\
\text { Hata }\end{array}$ & $\beta$ & $\mathrm{t}$ & p. & $\mathrm{F}$ & $\mathrm{R}^{2}$ & $\Delta \mathrm{R}^{2}$ \\
\hline Sabit & 2.13 & .604 & & 3.53 & .001 & & \\
Kendini Adama & -.263 & .215 & -.145 & -1.22 & .224 & & \\
Mevdan Okuma & -.033 & .226 & -.020 & -.144 & .885 & .884 & .016 & -.002 \\
Kontrol & .322 & .242 & .167 & 1.32 & .186 & & & \\
\hline
\end{tabular}

Tablo 5'te görüldüğü üzere; Kendini Adama (H4) ( $\beta=-.145 ; \mathrm{p}>0$,05), meydan okuma (H5) $(\beta=-.020 ; p>0,05)$ ve kontrol (H6)'ün $(\beta=.167 ; p>0,05)$ psiko-somatik faktörleri etkilemediği saptanmıştır. Elde edilen sonuçlara göre (H4), (H5) ve (H6) reddedilmiştir.

Çalışmada H7. (Kendini adama ekonomik faktörleri negatif yönde etkiler), H8. (Meydan okuma ekonomik faktörleri negatif yönde etkiler), H9. (Kontrol ekonomik faktörleri negatif yönde etkiler) test etmek için regresyon analizi yapılmış ve sonuçları Tablo 6'da gösterilmiştir.

Tablo 6. Kendini Adama, Meydan Okuma ve Kontrolün Ekonomik Faktörleri Etkilemesine İlişkin Regresyon Analizi Sonuçları

\begin{tabular}{lcccccccc}
\hline \multicolumn{1}{c}{ Bağımlı Değisken: Ekonomik Faktörler } \\
\hline Model & $\mathrm{B}$ & $\begin{array}{c}\text { Standart } \\
\text { Hata }\end{array}$ & $\beta$ & $\mathrm{t}$ & $\mathrm{p}$. & $\mathrm{F}$ & $\mathrm{R}^{2}$ & $\Delta \mathrm{R}^{2}$ \\
\hline Sabit & 2.23 & .600 & & 3.72 & .000 & & \\
Kendini Adama & -.090 & .214 & -.050 & -.420 & .675 & \\
Meydan Okuma & .009 & .225 & .005 & .038 & .970 & & \\
Kontrol & .213 & .241 & .112 & .008 & -.010 \\
\hline
\end{tabular}


Tablo 6'daki görüldüğü üzere; Kendini adama (H7) $(\beta=-.050 ; p>0,05)$, meydan okuma (H8) $(\beta=.005 ; \mathrm{p}>0,05)$ ve kontrol (H9)'un $(\beta=.112 ; \mathrm{p}>0,05)$ ekonomik faktörleri etkilemediği belirlenmiştir. Bu sonuçlara göre (H7), (H8) ve (H9) reddedilmiştir.

Araştırmada H10. (Kendini adama sosyal faktörleri negatif yönde etkiler), H11. (Meydan okuma sosyal faktörleri negatif yönde etkiler), H12. (Kontrol sosyal faktörleri negatif yönde etkiler) test etmek için regresyon analizi yapılmış ve sonuçları Tablo 7'de gösterilmiştir.

Tablo 7. Kendini Adama, Meydan Okuma ve Kontrolün Sosyal Faktörleri Etkilemesine İlişkin Regresyon Analizi Sonuçları

\begin{tabular}{lcccccccc}
\hline \multicolumn{1}{c}{ Bağımlı Değisken: Sosval Faktörler } \\
\hline \multicolumn{1}{c}{ Model } & $\mathrm{B}$ & $\begin{array}{c}\text { Standart } \\
\text { Hata }\end{array}$ & $\beta$ & $\mathrm{t}$ & $\mathrm{p}$. & $\mathrm{F}$ & $\mathrm{R}^{2}$ & $\Delta \mathrm{R}^{2}$ \\
\hline Sabit & 3.16 & .542 & & 5.83 & .000 & & \\
Kendini Adama & .103 & .193 & .064 & .534 & .594 & & \\
Meydan Okuma & -.104 & .203 & -.072 & -.513 & .608 & .005 & -.013 \\
Kontrol & .113 & .217 & .066 & .518 & .605 & & \\
\hline
\end{tabular}

Tablo 7'de görüldüğü üzere; Kendini adama $(\mathrm{H} 10)(\beta=.064 ; \mathrm{p}>0,05)$, meydan okuma (H11) $(\beta=-.072 ; \mathrm{p}>0,05)$ ve kontrol $(\mathrm{H} 12)$ 'nin $(\beta=.066 ; \mathrm{p}>0,05)$ sosyal faktörleri etkilemediği tespit edilmiştir. Elde edilen sonuçlara göre (H10), (H11) ve (H12) reddedilmiştir.

Genel olarak ise psikolojik dayanıklılı̆̆ın Covid-19 korkusu üzerindeki etkisini belirlemek için regresyon analizi yapılmıştır.

Tablo 8. Psikolojik Dayanıklılığın Covid-19 Korkusunu Etkilemesine İlişkin Regresyon Analizi Sonuçları

\begin{tabular}{lcccccccc}
\hline \multicolumn{10}{c}{ Bağımlı Değisken: Covid-19 Korkusu } \\
\hline \multirow{2}{*}{ Model } & $\mathrm{B}$ & $\begin{array}{c}\text { Standart } \\
\text { Hata }\end{array}$ & $\beta$ & $\mathrm{t}$ & $\mathrm{p}$. & $\mathrm{F}$ & $\mathrm{R}^{2}$ & $\Delta \mathrm{R}^{2}$ \\
\hline Sabit & 2.62 & .381 & & 6.88 & .000 & 1.59 & .009 & .004 \\
Psikoloiik & .122 & .097 & .097 & 1.26 & .209 & & & \\
\hline
\end{tabular}

Tablo 8'de görüldüğü üzere; Genel olarak psikolojik dayanıklılığın Covid-19 korkusunu etkilemediği görülmüştür $(\beta=.097 ; \mathrm{p}>0,05)$.

\section{SONUÇ ve ÖNERILLER}

İnsanların yaşadıkları sorunların üstesinden gelerek, bir an önce hayata adapte olabilmelerinde psikolojik dayanıklılık seviyesinin önemli rolü bulunmaktadır (Ekşi vd., 2018: 1698). Toplumsal bir varlık olan bireyin, başkaları ile yaşadığı 
birtakım ilişkilerinde iyimser tutum sergilemesi sonucu bencil davranma eğiliminin azalması söz konusu olur. $\mathrm{Bu}$ davranış eğilimi ise psikolojik dayanıklılık seviyesinde artı̧̧ yaratarak insanların ruh sağlığına pozitif etki etmektedir (Parmaksız, 2019: 289). Nitekim Covid-19'un psikolojik etkilerinin oldukça büyük çapta olduğu belirtilmektedir. Böyle korkuları değerlendirmenin de önemli olduğu belirtilmektedir (Pakpour ve Griffiths, 2020).

$\mathrm{Bu}$ araştırmada psikolojik dayanıklılık ve Covid-19 korkusu konuları bir arada ele alınmıştır. Alanyazında psikolojik dayanıklılığın Covid-19 korkusu üzerine etkisi inceleyen herhangi bir araştırmaya rastlanılamamıştır. Böyle bir araştırmanın AVM çalışanları üzerinde gerçekleştirilmediği de tespit edilmiştir. Bütün bunların araştırmanın özgünlüğünü ortaya koyması ve yazındaki boşluğu doldurması açısından önem taşıdığı düşünülmüştür. $\mathrm{Bu}$ doğrultuda araştırmada psikolojik dayanıklılık ve boyutlarının (kendini adama, meydan okuma ve kontrol) Covid-19 korkusu ve boyutları (psikolojik faktörler, psiko-somatik faktörler, ekonomik faktörler ve sosyal faktörler) üzerine etkisini incelenmiştir.

Araştırma verilerini test etmek amaciyla SPSS 25.0 yazılım programından faydalanılmıştır. Araştırma verileri frekans analizi, güvenirlik analizi, korelasyon analizi ve regresyon analiziyle test edilmiştir. Araştırmanın sonuçları hakkında genel bir değerlendirmede bulunmak gerekirse; psikolojik dayanıklılık ve boyutlarının (kendini adama, meydan okuma ve kontrol) Covid-19 korkusu ve boyutlarını (psikolojik faktörler, psiko-somatik faktörler, ekonomik faktörler ve sosyal faktörler) etkilemediği saptanmıştır. Araştırmadan beklenilen sonuç psikolojik dayanıklılık ve boyutlarının Covid-19 korkusu ve boyutlarını azaltacağ1 yönündeydi. Fakat beklenilen bu sonucun araştırmada teyit edilemediği görülmektedir. Araştırma sonuçlarına dayanarak hipotezlerin tamam1 (H1), (H2), (H3), (H4), (H5), (H6), (H7), (H8), (H9), (H10), (H11) ve (H12) regresyon analizi sonucunda reddedilmiştir. Nitekim alanyazın incelendiğinde bu araştırmanın bulgularıyla benzer ya da çelişen sonuçlara rastlanılamadığı için karşılaştırma yapmak mümkün olmamıştır. Her ne kadar bu araştırmada teyit edilemese de çalışanların Covid-19'a yönelik korkularını azaltmak için psikolojik dayanıklılıklarını artıran etmenlere önem verilmesi gerektiği söylenebilir. Çünkü bu salgın döneminde psikolojik dayanıklılık düzeyi yüksek çalışanların Covid-19 korkusuyla mücadelede daha etkin olabilecekleri düşünülmektedir. Covid-19'un bütün dünyayı neredeyse tehdit ettiği göz önüne alındığında, Covid-19 korkusunu azaltmada psikolojik dayanıklılık seviyesi yüksek çalışanlara sahip örgütler, bununla mücadelede daha başarılı olabileceklerdir.

Araştırmanın sonuçlarıyla ilgili olarak gelecekte yapılması planlanan çalışmalar için araştırmacılara aşağıda bazı önerilerde bulunulmuştur. 
Gelecekte yapılacak psikolojik dayanıklılık konulu araştırmalar, AVM sayısı artırılarak yapılabilir.

Psikolojik dayanıklı1ık konulu araştırmalar gerek kamu gerekse özel sektördeki farklı örneklemler üzerinde uygulanabilir.

Psikolojik dayanıklılıkla ilgili gelecekteki araştırmalara farklı ve yeni değişkenler eklenebilir. Bunların psikolojik dayanıklılıkla olan aracılık ilişkileri incelenebilir.

Psikolojik dayanıklılıkla ilgili gelecekteki araştırmalarda nitel ve karma yöntemlerden faydalanılabilir.

$\mathrm{Bu}$ araştırmada psikolojik dayanıklılığın (kendini adama, meydan okuma ve kontrol) Covid-19 korkusuna (psikolojik faktörler, psiko-somatik faktörler, ekonomik faktörler ve sosyal faktörler) etkisi sonucu elde edilen bulgular, gelecekte yapılacak başka araştırmaların bulgularıyla desteklenebilir.

\section{KAYNAKÇA}

Akbaba, A. (2020). Öğretmen adaylarının mutluluk, duygusal zekâ ve psikolojik dayanıklılıklarının incelenmesi. Mustafa Kemal Üniversitesi Eğitim Fakültesi Dergisi, 4(6), 179-191.

Aktaş, S. (2020). Küresel sağlıktan sağlık turizmine Covid-19. Türk Coğrafya Dergisi, 76, 107-114.

Altan, S. (2019). Psikolojik Dayanıklılı̆̆ın işten ayrılma niyeti üzerine etkisi: Örgütsel vatandaşlık davranışının aracılık rolü. Avrasya Sosyal ve Ekonomi Araştırmaları Dergisi, 6(3), 612-629.

Altunışık, R., Coşkun, R., Bayraktaroğlu, S. ve Yıldırım, E. (2010). Sosyal bilimlerde araştırma yöntemleri SPSS uygulamaları (6. bs.). Sakarya.

Arpac1, İ., Karataş, K. ve Baloğlu, M. (2020). The development and initial tests for the psychometric properties of the Covid-19 phobia scale (C19P-S). Personality and Individual Differences, 164, 1-6.

Atan, T. ve Ünver, Ş. (2019). Spor Bilimleri Fakültesi ve İlahiyat Fakültesi öğrencilerinin psikolojik dayanıklılık düzeylerinin karşılaştırılması. Uluslararası Toplum Araştırmaları Dergisi, 14(2), 207-222.

Aydın, B. ve Doğan, M. (2020). Yeni Koronavirüs (Covid-19) pandemisinin turistik tüketici davranışları ve Türkiye turizmi üzerindeki etkilerinin 
değerlendirilmesi. Pazarlama Teorisi ve Uygulamaları Dergisi, 6(1), 93115.

Baykal, E. (2020). Covid-19 bağlamında psikolojik dayanıklılık, kaygı ve yaşam doyum ilişkisi. International Journal of Social and Economic Sciences, 10(2), 68-80.

Bayram, N. (2009). Sosyal bilimlerde SPSS ile veri analizi. Ezgi.

Binbaşıoğlu, H. (2020). Yeni tip Koronavirüs (Covid-19) döneminde ulusal turizm örgütlerinin resmî web sitelerinin bir iletişim aracı olarak incelenmesi. Turizm Akademik Dergisi, 7(2), 73-88.

Bitmiş, G., Sökmen, A. ve Turgut, H. (2013). Psikolojik dayanıklılı̆̆ın tükenmişlik üzerine etkisi: Örgütsel özdeşleşmenin aracilık rolü. Gazi Üniversitesi İktisadi ve İdari Bilimler Fakültesi Dergisi, 15(2), 27-40.

Boyacı, İ. (2020). Türkiye sağlık sisteminin dönüşümü (2003-13): Covid-19 pandemisi ile mücadele sürecinde sağlık reformlarına yeniden bakış. İstanbul Ticaret Üniversitesi Sosyal Bilimler Dergisi, Covid-19 Sosyal Bilimler Özel Sayısl, 37, 59-80.

Bozkurt, Y., Zeybek, Z. ve Aşkın, R. (2020). Covid-19 pandemisi: psikolojik etkileri ve terapötik müdahaleler. Ístanbul Ticaret Üniversitesi Sosyal Bilimler Dergisi, 19(37), 304-318.

Buchecker, M., and Degenhardt, B. (2015). The Effects of urban inhabitants nearby outdoor recreation on their well-being and psychological resilience. Journal of Outdoor Recreation and Tourism, 10, 55-62.

Bulut, R. ve Pınar, C. (2020). Covid-19 pandemisi döneminde Türkiye'de istihdam ve işsizlik. Burdur Mehmet Akif Ersoy Üniversitesi Oğuzhan Sosyal Bilimler Dergisi, 2(2), 217-225.

Buz, S. ve Genç, B. (2019). Sosyal hizmet uzmanları için psikolojik dayanıklılığın önemi. Toplum ve Sosyal Hizmet, 30(2), 623-642.

Büyükbayram, A., Baysan Arabacı, L., Taş, G. ve Varol, D. (2016). Öğrenci hemşirelerin duygusal zekâ ve sosyotropi-otonomi kişilik özellikleri ile psikolojik dayanıklılıkları arasındaki ilişki. İzmir Kâtip Çelebi Üniversitesi Să̆llk Bilimleri Fakültesi Dergisi, 1(3), 29-37.

Büyüköztürk, Ş. (2009). Sosyal bilimler için veri analizi el kitabı. Pegem. 
Ceylan, R.F. ve Özkan, B. (2020). The economic effects of epidemics: From sars and mers to Covid-19. Research Journal in Advanced Humanities, 1(2), 21-29.

Çavuşoğlu, S. ve Yalçın, M. (2018). Banka çalışanlarının kişilik özelliklerinin psikolojik dayanıklılık düzeylerine etkisi. Manisa Celal Bayar Üniversitesi Sosyal Bilimler Dergisi, 16(2), 50-76.

Çetin, F. Yeloğlu, H.O. ve Basım, N. (2015). Psikolojik dayanıklılı̆̆ın açıklanmasında beş faktör kişilik özelliklerinin rolü: Bir kanonik ilişki analizi. Türk Psikoloji Dergisi, 30(75), 81-92.

Doğan, T. (2015). Kısa psikolojik sağlamlık ölçeği'nin Türkçe uyarlaması: Geçerlik ve güvenirlik çalışması. The Journal of Happiness and WellBeing, 3(1), 93-102.

Duygun, A. (2020). Covid-19 pandemisi sırasında tüketicilerin yaşam tarzlarının değerlendirilmesi. International Academic Journal (Econder), 4(1), 232247.

Ekşi, H., Boyalı, C. ve Ümmet, D. (2018). Öğretmen adaylarının spiritüel iyi oluş ile yaşamda anlam değiş̧enlerinin psikolojik dayanıklılığı yordaması: Bir yapısal eşitlik modeli denemesi. Kastamonu Ĕ̆itim Dergisi, 27(4), 1695-1704.

Erkutlu, H. ve Soyumert, N. (2020). Örgütsel politika algısı ve örgütsel sessizlik arasındaki ilişkide psikolojik dayanıklılı̆̆ın düzenleyici rolü. Journal of Organizational Psychology and Behavior, 1(1), 1-14.

Field, A.P. (2009). Discovering statistics using SPSS. ( $3^{\text {rd }}$ ed.). Sage.

Fletcher, D., and Sarkar, M. (2013). Psychological resilience: A review and critique of definitions, concepts and theory. European Psychologist, 18(1), 12-23.

Folkman, S., and Lazarus, R.S. (1990). Coping and emotion. In N.L. Stein, B. Leventhal, and T. Trabasso (Eds.), Psychological and biological approaches to emotion (pp. 313-332). Lawrence Erlbaum Associates.

Friborg, O., Hjemdal, O., Rosenvinge, J.H., and Martınussen, M. (2003). A new rating scale for adult resilience: What are the central protective resources behind healthy adjustment? International Journal of Methods in Psychiatric Research, 12(2), 65-76. 
Garmezy, N. (1991). Resilience and vulnerability to adverse developmental outcomes associated with poverty. American Behavioral Scientist, 34(4), 416-430.

Güngörmüş, K., Okanl1, A. ve Kocabeyoğlu, T. (2015). Hemşirelik öğrencilerinin psikolojik dayanıklılıkları ve etkileyen faktörler. Psikiyatri Hemşireliği Dergisi, 6(1), 9-14.

Hjemdal, O., Friborg, O., Martinussen, M., and Rosenvinge, J.H. (2001). Preliminary results from the development and validation of a Norwegian scale for measuring adult resilience. Journal of The Norwegian Psychological Association, 38(4), 310-317.

Holt, P., Fine, M.J., and Tollefson, N. (1987). Mediating stress: survival of the hardy. Psychology in the Schools, 24(1), 51-58.

Işık, Ş. (2016). Psikolojik dayanıklılık ölçeği'nin geliştirilmesi: Geçerlik ve güvenirlik çalışması. The Journal of Happiness and Well-Being, 4(2), 165-182.

Izgar, H., Gürsel, M., Kesici, Ş. ve Negiş, A. (2004). Önder davranışlarının problem çözme becerisine etkisi. XIII. Ulusal Eğitim Bilimleri Kurultayı, 6-9 Temmuz 2004 İnönü Üniversitesi, Eğitim Fakültesi, Malatya.

İslamoğlu, E. ve Kirtulukoğlu, E. (2017). Otel işletmelerinde psikolojik dayanıklılık ve yöneticilerin adalet algıları arasındaki ilişki üzerine bir araştırma. Organizasyon ve Yönetim Bilimleri Dergisi, 9(2), 24-36.

Jacelon, C.S. (1997). The trait and process of resilience. Journal of Advanced Nursing, 25(1), 123-129.

Jiang, F., Deng, L., Zhang, L., Cai, Y., Cheung, C.W., and Xia, Z. (2020). Review of the clinical characteristics of coronavirus disease 2019 (Covid-19). Journal of General Internal Medicine, 35(5), 1545-1549.

Kaba, İ. ve Keklik, İ. (2016). Öğrencilerin üniversite yaşamına uyumlarında psikolojik dayanıklılık ve psikolojik belirtiler. Hacettepe Üniversitesi Eğitim Bilimleri Enstitüsü Ĕgitim Araştırmaları Dergisi, 2(2), 98-111.

Kamya, H.A. (2000). Hardiness and spiritual well-being among social work students: Implications for social work education. Journal of Social Work Education, 36(2), 231-240.

Kanbur, E., Kanbur, A. ve Özdemir, B. (2017). Psikolojik dayanıklılık ile örgütsel vatandaşlık davranışı arasındaki ilişkide iş doyumunun aracılık 
rolü: Havacılık sektöründe bir araştırma. İş ve insan dergisi, 4(2), 127141.

Karasar, N. (2005). Bilimsel araştırma yöntemi: Kavramlar, ilkeler, teknikler. Nobel.

Kavi, E. ve Karakale, B. (2018). Çalışan psikolojisi açısından psikolojik dayanıklılık. Hak-İS Uluslararası Emek ve Toplum Dergisi, 7(17), 55-77.

Kaya, D.G. (2020). Covid-19 pandemisinin küresel ekonomideki izleri: Kamu finansman dengesi, ticaret hacmi, enflasyon, isssizlik ve ekonomik büyüme. Avrasya Sosyal ve Ekonomi Araştırmaları Dergisi, 7(5), 221237.

Kayış, A. (2008). SPSS uygulamalı çok değişkenli istatistik teknikleri. (3. bs.), Ş. Kalaycı (Editör). Asil.

Kılınç, G., Yıldız, E. ve Kavak, F. (2019). Koah'lı hastalarda psikolojik dayanıklılık ve yaşam doyumu arasındaki ilişki. Psikiyatri Hemşireliği Dergisi, 10(2), 111-116.

Klag, S., and Bradley, G. (2004). The role of hardiness in stress and illness: An exploration of the effect of negative affectivity and gender. British Journal of Health Psychology, 9(2), 137-161.

Kobasa, S. (1979). Stressful life events, personality and health: An inquiry into hardiness. Journal of Personality and Social Psychology, 37(1), 1-11.

Kobasa, S.C., Maddi, S.R., and Kahn, S. (1982). Hardiness and health: A prospective study. Journal of Personality and Social Psychology, 42(1), 168-177.

Kobasa, S.C., and Puccetti, M.C. (1983). Personality and social resources in stress resistance. Journal of Personality and Social Psychology, 45(4), 839-850.

Köse, S., Çakan, S. ve Terzi, D. (2018). Örgütsel adaletsizliğin örgütsel dışlanmaya etkisinde psikolojik dayanıklılığın aracı rolü. İsletme Bilimi Dergisi, 6(1), 245-264.

Kurtuluş, K. (2004). Pazarlama araştırmaları (7. bs.). Literatür.

Lambert, V.A., Lambert, C.E., and Yamase, H. (2003). Psychological hardiness, workplace stress and related stress reduction strategies. Nursing and Health Sciences, 5(2), 181-184. 
Maddi, S.R. (2013). Hardiness-turning stressful circumstances into resilient growth. Springer.

Maddi, S.R. (2004). Hardiness: An operationalization of existential courage. Journal of Humanistic Psychology, 44(3), 279-298.

Maddi, S.R. Harvey, R.H., Khoshaba, D.M., Lu, J.N., Perciso, M., and Brow, M. (2006). The personality construct of hardiness, III: Relationships with repression. Journal of Personality, 74(2), 575-598.

Masten, A.S., and Obradovic, J. (2006). Competence and resilience in development. Annals of The New York Academy of Sciences, 1094, 1327.

Masten, A.S., and Reed, M.J. (2002). Resilience in Development. (Ed. C.R. Snyder, \& S.J. Lopez), Handbook of Positive Psychology, Oxford University, (pp. 74-88).

Mc Ewen, K. (2011). Building resilience at work. Australia: Australian Academic.

Motan, İ. ve Gençöz, F. (2009). Psikolojik dayanıklılığı nasıl ölçebiliriz? Bir Türk örnekleminde Kişisel Görüş Ölçeği'nin geçerlik ve güvenilirlik çalışması. Kriz Dergisi, 17(1), 1-11.

Nakip, M. (2006). Pazarlama araştırmalart, teknikler ve (SPSS destekli) uygulamalar). (2. bs.), Seçkin.

Niewiadomski, P. (2020). Covid-19: from temporary de-globalisation to a rediscovery of tourism? Tourism Geographies, 22(3), 651-656.

Oktan, V. (2012). Psikolojik sağlamlığın gelişiminde bir moderator olarak umut. International Journal of Human Sciences, 9(2), 1691-1701.

Özdemir, L. (2020). Covid-19 pandemisinin BİST sektör endeksleri üzerine asimetrik etkisi. Finans Ekonomi ve Sosyal Araştırmalar Dergisi, 5(3), 546-556.

Öztürk, K. ve Erdem, M. (2020). Ortaokul öğretmenlerinin algılarına göre okul müdürlerinin yönetici yeterlikleri ile öğretmenlerin psikolojik dayanıklılık düzeyleri arasındaki ilişki. Uluslararası Türk Eğitim Bilimleri Dergisi, 8(15), 26-47.

Pakpour, A.H., and Griffiths, M.D. (2020). The fear of Covid-19 and its role in preventive behaviors. Journal of Concurrent Disorders, 2(1), 58-63. 
Paksoy, H.M. (2020). Covid-19 pandemisi ile oluşan korku ve davranışlara inancın etkisi üzerine bir araştırma: Türkiye örneği. Kahramanmaraş Sütçü İmam Üniversitesi İktisadi ve İdari Bilimler Fakültesi Dergisi, 10(2), 135-155.

Parmaksız, İ. (2020). İyimserlik, özgecilik ve medeni durumun psikolojik dayanıklılık üzerindeki etkileri. Pamukkale Üniversitesi Eğitim Fakültesi Dergisi, 48, 285-302.

Polatcı, S., Irk, E., Gültekin, Z. ve Sobacı, F. (2017). Psikolojik dayanıklılık ve kişilik özellikleri tatmin düzeyini etkiler mi? Süleyman Demirel Üniversitesi Sosyal Bilimler Enstitüsü Dergisi, 29, 553-578.

Saltık, Z. ve Kızılırmak, İ. (2020). Profesyonel turist rehberlerinde stres yönetimi ve psikolojik dayanıklılığın ölçülmesi. Seyahat ve Otel Işsletmeciliği Dergisi, 17(1), 53-70.

Sezgin, F. (2009). Relationships between teacher organizational commitment, psychological hardiness and some demographic variables in Turkish primary schools. Journal of Educational Administration, 47(5), 630-651.

Sezgin, F. (2012). İlköğretim okulu öğretmenlerinin psikolojik dayanıkl1lık düzeylerinin incelenmesi. Kastamonu Ĕ̌itim Dergisi, 20(2), 489-502.

Şahin, T. ve Güçlü, M. (2018). Sporcularda psikolojik dayanıklılığın duygu düzenleme becerilerine etkisi: Türkiye Korumalı Futbol 1. Ligi oyuncuları örneği. Spormetre, 16(3), 204-216.

Şit, A. ve Telek, C. (2020). Covid-19 pandemisinin altın ons fiyatı ve dolar endeksi üzerine etkileri. Gaziantep Üniversitesi Sosyal Bilimler Dergisi, 19, 1-13.

Tambulut, A. ve Eker, E. (2019). Bakıcı annelerin ebeveyn rolüne ilişkin kendilik algıs1, psikolojik dayanıkl11ıkları ve depresyon düzeylerinin demografik değişkenler ile ilişkisinin incelenmesi. Sosyal Çalışma Dergisi, 3(2), 147-176.

Terzi, Ş. (2016). Üniversite öğrencilerinin psikolojik dayanıklılıkları ve algıladıkları sosyal destek arasındaki ilişki. Türk Psikolojik Danışma ve Rehberlik Dergisi, 3(29), 1-11.

Turgut, H., Soran, S. ve Ateş, M.F. (2017). Örgütsel özdeşleşme işten ayrılma niyeti ilişkisinde psikolojik dayanıklılığın aracı rolü. Uluslararası İktisadi ve İdari Incelemeler Dergisi, 16, 577-592. 
Ülker Tümlü, G. ve Recepoğlu, E. (2013). Üniversite akademik personelinin psikolojik dayanıklılık ve yaşam doyumu arasındaki ilişki. Yüksekögretim ve Bilim Dergisi, 3(3), 205-213.

Ünal, S. (2020). Covid-19 salgınında Borsa İstanbul şirketlerinin fiyatlamalarının etkinliği. Ekonomi, Politika ve Finans Araştırmaları Dergisi, 5, 13-31.

Üzüm, B. ve Şenol, L. (2020). Psikolojik dayanıklılık ve üretim karşıtı iş davranışları ilişkisi: Hastane çalışanları örneği. Iğdır Üniversitesi Sosyal Bilimler Dergisi, 21, 455-470.

Williams, A. (2001). A literature review on the concept of intimacy in nursing. Journal of Advanced Nursing, 33(5), 660-667.

Yıldırımvuran, S., Milanlığlu, U.K. ve Çakan, S. (2020). Covid-19 pandemi sürecinin Türk yarg1 sistemine etkileri. Türk Кати Yönetimi Dergisi, 1(1), 47-54. 